\title{
Prebiotic effect of porang oligo-glucomannan using fecal batch culture fermentation
}

\author{
ANGGELA $^{1,2}$ (D), Eni HARMAYANI ${ }^{1}$, Widiastuti SETYANINGSIH ${ }^{1}$, Santad WICHIENCHOT ${ }^{2 *}$
}

\begin{abstract}
Porang glucomannan is a polysaccharide extracted from Amorphophallus oncophylus and its degradation product is porang oligoglucomannan (POG). It contains glucomannan, which has been used as an emulsifier, thickener, or as a nutritional supplement to counter many diseases. While it is believed to have health benefits, there are only limited studies exploring this aspect of porang glucomannnan (PGM). It was hydrolyzed using $\beta$-mannanase to obtain POG under optimal conditions: reaction temperature of $37^{\circ} \mathrm{C}$, reaction time of $4 \mathrm{~h}, \mathrm{pH} 5.5$ and E/S of 1:1,000 (w/w). The study aimed to evaluate the fermented POG, which might also generate short-chain fatty acids (SCFA) and to estimate the prebiotic activity score of POG fermented in vitro. The results show that SCFA profiles of POG fermentation gave a high acetic acid concentration (32.64 mM) and butyric acid $(6.68 \mathrm{mM})$ at $12 \mathrm{~h}$, having butyrogenic effects after a rapid fermentation. Mostly the beneficial bacteria grew faster on POG and KOG (konjac oligo-glucomannan) than on PGM or control at the beginning of incubation. Among the substrates screened, POG showed a highly positive prebiotic index of 10.29 , increasing bifidobacteria and lactobacilli but reducing bacteroides population. So, POG is a candidate prebiotic since it has bifidogenic, butyrogenicity, and fermentability.
\end{abstract}

Keywords: porang oligo-glucomannan; gut modulation; prebiotic; short chain fatty acid.

Practical Application: POG ingredient has low viscosity compared to a native porang glucomannan (PGM) thus it is excellent supplemented in functional drinks and dairy products.

\section{Introduction}

Porang is native plant in Indonesia and grows in forest areas of East Java (Madiun, Bojonegoro, Nganjuk, and Ngawi), which is a region with high porang production potential in Indonesia (Budi et al., 2018). Porang tuber has been reported as a source of glucomannan, which can be extracted from porang flour by suspending in water at $55{ }^{\circ} \mathrm{C}$ and coagulating glucomannan using ethanol (Harmayani et al., 2014). They found that porang glucomannan supplementation can hinder the growth of $E$. coli by enhancing SCFA production thus decrease the $\mathrm{pH}$ to suppress pathogens. SCFA are mainly metabolites from carbohydrate fermentation by microbial metabolism. Acidity of colonic environment influences for manipulating microbial composition selectively by lowering $\mathrm{pH}$ of colonic content in the human colon resulted in suppression of harmful bacteria i.e., pathogens which affect to human health (Scott et al., 2012). The health properties of glucomannan have been investigated as having prebiotic potential, with applications in health foods and pharmaceuticals (Behera \& Ray, 2016) by inhibiting pathogens, stimulating immunity, reducing blood lipid levels, reducing insulin resistance, influencing brain function, providing energy and mineral bioavailability (Gibson et al., 2017).

SCFA production to provide energy for epithelial cells and improve the colon health (Donohoe et al., 2011). As acetic acid is primarily SCFA that can be absorbed and transported directly into systemic circulation for use in lipogenesis, while propionate is transported to the liver for use in gluconeogenesis (Sossai, 2012). Although not only bifidobacteria is acetic acid producer, but most anaerobes in the colon produce acetic acid which against epithelial cell infection (Tedelind et al., 2007). An important SCFA for gut health is butyric acid that has been reported as a major energy source for colonocytes, and it is produced by Faecalibacterium sp. and Eubacterium sp. (Scott et al., 2008; Flint et al., 2012). Previous studies have demonstrated that glucomannan fermentation either in vitro or in vivo produces SCFA (acetic acid, propionic acid and butyric acid) (Chen et al., 2008; Connolly et al., 2010; Harmayani et al., 2014). But the hydrolyzed glucomannan with a lower molecular weight is more selective in enhanced butyrate production and increase of desirable bacteria (Ariestanti et al., 2019).

Prebiotic is a substrate that is selectively utilized by host microorganisms conferring a health benefit (Gibson et al., 2017). Based on this, it is possible to degrade porang glucomannan by enzymatic hydrolysis to small compounds i.e., oligo-glucomannan that might be prebiotics, with ability to selectively stimulate the growth of probiotic bacteria. Actually, PGM is a prebiotic candidate can resist digestion in the upper gut, so it can pass through into the colon and be fermented by beneficial bacteria such as Bifidobacterium or Lactobacillus (Connolly et al., 2010). So far, there is limited information on porang glucomannan potential as regards its health benefits from supporting selectively

Received 04 Feb., 2021

Accepted 05 July, 2021

${ }^{1}$ Department of Food and Agricultural Product and Technology, Faculty of Agricultural Technology, Universitas Gadjah Mada, Yogyakarta, Indonesia

${ }^{2}$ Functional Food and Nutrition Program, Center of Excellence in Functional Foods and Gastronomy, Faculty of Agro-Industry, Prince of Songkla University, Hat Yai, Songkhla, Thailand.

*Corresponding author: santad.w@psu.ac.th 
the growth of bacterial populations. Particularly stimulating on growth of bifidobacteria so it is claimed as bifidogenic effect and generating SCFA, especially butyric acid so it is claimed as butyrogenic effect. A colonic system using $\mathrm{pH}$-controlled batch culture fermentation with human fecal slurries was employed to evaluate the bacterial growth modulation of mainly beneficial bacteria by fluorescence in situ hybridization (FISH), and SCFA production was investigated by gas chromatography. Moreover, to assess prebiotic effects of POG, KOG and PGM, microbial populations were determined to assess the prebiotic activity by calculating of prebiotic index (PI).

\section{Materials and methods}

\subsection{Materials}

Porang oligo-glucomannan (POG) was obtained from previous studied by Anggela et al. (2020). Their process was started by suspension of PGM flour in sodium acetate buffer ( $\mathrm{pH}$ 5.5). Addition of $\beta$-mannanase to obtain $\mathrm{E} / \mathrm{S}$ of 1:1,000 (w/w), incubated for $4 \mathrm{~h}$ at $37^{\circ} \mathrm{C}$ then boiled samples for inactivating enzyme, and separated the POG by centrifugation. The compositions of POG were $99.45 \%$ oligosaccharide content with the degree of polymerization (DP) of 3 . Porang glucomannan (PGM) was obtained from Agricultural Faculty, Universitas Gadjah Mada (Yogyakarta, Indonesia). The composition of PGM was $96.12 \%$ indigestible carbohydrates which mainly mannan polysaccharide (Harmayani et al., 2014). Konjac oligo-glucomannan (KOG) was obtained from the previous study of Ariestanti et al. (2019) as a comparative sample. The composition of KOG was $62.80 \%$ oligosaccharide (average DP of 8 ) and $37.20 \%$ polysaccharide. The rRNA-targeted oligonucleotide probes including Bif164, Lab158, Chis150, Bac303, and Eub338 used for fluorescence in situ hybridization (FISH) analysis were purchased from Sigma-Aldrich.

\subsection{Methods}

\section{Collection and preparation of fecal slurry}

The fecal samples placed specific criteria on the volunteers. Inclusion criteria were healthy subjects with age range from 25 to 40 years old. They had been on a normal diet. Exclusion criteria were neither taking any antibiotics nor medicines 3 months before donating the feces, as well as having no surgery or a history of any gastrointestinal disorder. The fresh feces were collected from 4 volunteers to prepare fecal slurry for use in the batch culture system. Fecal slurry was prepared by diluting fresh feces with 1:10 (w/v) in sterile $0.1 \mathrm{M}$ phosphate buffer saline (PBS; $8 \mathrm{~g} / \mathrm{l}$ $\mathrm{NaCl}, 0.2 \mathrm{~g} / \mathrm{l} \mathrm{KCl}, 1.44 \mathrm{~g} / \mathrm{N} \mathrm{Na}_{2} \mathrm{HPO}_{4}$ and $0.24 \mathrm{~g} / \mathrm{l} \mathrm{KH}_{2} \mathrm{PO}_{4}$ ) at $\mathrm{pH}$ 7.4. Then, it was homogenized by using a blender (Seward, West Sussex, UK) for $2 \mathrm{~min}$ at 350 paddle-beats per min, and the slurry was filtered to a Stomacher bag with a strainer before inoculation into the vessel (Plongbunjong et al., 2017).

\section{Fecal batch culture fermentation}

The sterile vessels ( $100 \mathrm{~mL}$ maximum volume) were prepared and filled with $90 \mathrm{~mL}$ sterile basal medium by aseptic technique.
The basal medium was sterilized at $121^{\circ} \mathrm{C}$ for $15 \mathrm{~min}$. The basal medium contained (per liter); peptone water $0.9 \mathrm{~g}$, yeast extract $0.9 \mathrm{~g}, \mathrm{NaCl} 0.045 \mathrm{~g}, \mathrm{~K}_{2} \mathrm{HPO}_{4} 0.018 \mathrm{~g}, \mathrm{KH}_{2} \mathrm{PO}_{4} 0.018 \mathrm{~g}$, $\mathrm{MgSO}_{4} 7 \mathrm{H}_{2} \mathrm{O} 0.0045 \mathrm{~g}, \mathrm{CaCl}_{2} 6 \mathrm{H}_{2} \mathrm{O} 0.0045 \mathrm{~g}, \mathrm{NaHCO}_{3} 0.9 \mathrm{~g}$, L-cysteine. $\mathrm{HCl} 0.225 \mathrm{~g}$, bile salt $0.225 \mathrm{~g}$, Tween $800.9 \mathrm{~mL}$, vitamin $\mathrm{K} 4.5 \mu \mathrm{L}$, hemin $0.0225 \mathrm{~g}$, and resazurin $0.025 \%$. The fecal fermentation was run in a batch culture system consisting of glass vessels connected to a circulating water bath controlled at $37^{\circ} \mathrm{C}$. The basal media in the vessel was flushed with $\mathrm{N}_{2}$ gas overnight to maintain anaerobic conditions before fecal slurry and sample addition. The $\mathrm{pH}$ of culture was controlled within the range $6.6-6.8 \mathrm{by} \mathrm{pH}$ controllers fed with either $0.1 \mathrm{M} \mathrm{NaOH}$ nor $0.1 \mathrm{M} \mathrm{HCl}$. Each vessel was inoculated with $10 \mathrm{~mL}$ fecal slurry into $90 \mathrm{~mL}$ basal media and then one gram of sample (POG, KOG or PGM) was added into each vessel to reach a final concentration of $1 \%(\mathrm{w} / \mathrm{w})$. The vessel contained basal media and fecal slurry without sample addition was used as a negative control. Samples $(5 \mathrm{~mL})$ were taken from each vessel at $0,12,24$ and $48 \mathrm{~h}$ fermentation for enumeration of gut microbiota and SCFA analysis using FISH technique and GC-FID, respectively.

\section{Gut microbiota determination by Fluorescent In Situ Hybridization (FISH)}

Determining bacterial populations was done by FISH analysis using $16 \mathrm{~S}$ rRNA oligonucleotide probes, with sampling at four timepoints during fermentation. The probe entered the cells and it was hybridized in the ribosome at a conserved region of the bacterial 16S rRNA (Hugenholtz et al., 2002). Each sample of a batch culture $(375 \mu \mathrm{L})$ was mixed and fixed overnight in cold $4 \%$ paraformaldehyde (pH 7.2) in the ratio 1:3 of sample to $4 \%$ paraformaldehyde $(\mathrm{v} / \mathrm{v})$. These samples were then centrifuged at $13,000 \mathrm{xg}$ for $20 \mathrm{~min}$ at $4{ }^{\circ} \mathrm{C}$. The supernatant was removed and the pellet was washed and then resuspended in $1 \mathrm{~mL}$ phosphate buffered saline of $7.4 \mathrm{pH}$ and centrifuged at 13,000 $\mathrm{xg}$ for $20 \mathrm{~min}$ at $4{ }^{\circ} \mathrm{C}$. Adding PBS and centrifugation were done in triplicates and the remaining pellets were resuspended in $150 \mu \mathrm{L}$ PBS, adding $150 \mu \mathrm{L}$ of $96 \%$ (v/v) ethanol and stored at $-20^{\circ} \mathrm{C}$ for up to 3 months.

The oligonucleotide probes used were commercially synthesized and labeled with the fluorescent dye Cy3 (Sigma Aldrich Co. Ltd, UK). For hybridization, $20 \mu \mathrm{L}$ of diluted sample was spread properly on a Teflon poly-L-lysine coated six-well microscope slide (Tekdon Inc, Myakka City, Florida, USA). The samples on the slide were dried at $46-50^{\circ} \mathrm{C}$ for $15 \mathrm{~min}$ for each concentration. The hybridization buffer (mixed probe and hybridization buffer $1: 9, \mathrm{v} / \mathrm{v}$ ) was added onto slide samples. For Lab158 samples were mixed with $20 \mu \mathrm{L}$ lysozyme at room temperature for $15 \mathrm{~min}$ before washing briefly for $30 \mathrm{~s}$ in water and dehydrating in an ethanol series. Then, slides were placed on hybridization oven for $4 \mathrm{~h}$ (Boekel Scientific InSlide Out Slide Hybridizer 241000, Pennsylvania, US). For the washing step, slides were placed in $50 \mathrm{~mL}$ of washing buffer containing $0.9 \mathrm{M} \mathrm{NaCl}$, $0.02 \mathrm{M}$ Tris/ $\mathrm{HCl}$ (pH 8.0), $0.005 \mathrm{M}$ ethylenediaminetetraacetic acid (EDTA) solution ( $\mathrm{pH} 8.0)$, warmed to the appropriate temperature for each probe.

They were then briefly washed ( $30 \mathrm{~s}$ ) in cold water and under a stream of compressed air. $10 \mu \mathrm{L}$ antifade reagent (Invitrogen, 
Thermo Fisher Scientific, Basingstoke, UK) was added to each well, and a cover was applied. Slides were stored in a dark room until cell counting under a Nikon E400 Eclipse microscope (Nikon, London, UK) for 15 randomized views from each well (Wichienchot et al., 2017) done by image analysis software NISElements BR 3.00, SP6 (Nikon Instruments, Inc, New York, USA).

\section{Prebiotic calculation}

Prebiotic activity can be assessed from the prebiotic index (PI). Calculation of PI (Palframan et al., 2002) is as follows (Equation 1):

$$
P I=(\text { Bif } / \text { Total })+(\text { Lac } / \text { Total })-(\text { Bac } / \text { Total })-(\text { Clos } / \text { Total })
$$

where Bif is the number of bifidobacteria, Lac is the number of lactobacilli, Bac is the number of bacteroides, and Clos is the number of clostridia. The PI is calculated by counting the cell number of each group of gut microbiota at 0,24 or $48 \mathrm{~h}$ fermentation divided by the cell number of eubacteria (total bacteria) at 0,24 or $48 \mathrm{~h}$ fermentation.

\section{Short chain fatty acids analysis by GC-FID}

A sample $(1125 \mu \mathrm{L})$ from each treatment was centrifuged at $13,000 \times \mathrm{g}, 4^{\circ} \mathrm{C}$ for $5 \mathrm{~min}$. The supernatant was collected and filtered through a membrane nylon filter $(0.22 \mathrm{~mm})$. Aliquots of the filtered supernatant were added with acetone in the ratio 1:1. External standards used to produce the standard curves were acetate, propionate, and butyrate. SCFA production was measured by gas chromatography (GC) coupled with flame ionization detector (FID). A fused-silica capillary column (HP-INNOWAX 19091N-1131, J\&W Scientific, Agilent Technologies Inc., USA) of $30 \mathrm{~m} \times 0.32 \mathrm{~mm}$ I.D coated with $0.25 \mu \mathrm{M}$ thick film was used. The initial oven temperature was at $60^{\circ} \mathrm{C}$ and was increased to $100{ }^{\circ} \mathrm{C}(2 \mathrm{~min})$ at $4{ }^{\circ} \mathrm{C} / \mathrm{min}$ rate, and finally to $230^{\circ} \mathrm{C}(5 \mathrm{~min})$ at $15^{\circ} \mathrm{C} / \mathrm{min}$ rate.

Helium gas flow was constant at $1.5 \mathrm{~mL} / \mathrm{min}$. Glass wool was inserted into the glass liner of the splitless injection port. FID and injection port were heated to $250{ }^{\circ} \mathrm{C}$. Flow rates of hydrogen, air, and nitrogen as a make-up gas were 30,300 , and $25 \mathrm{~mL} / \mathrm{min}$, respectively. Total volume injected for GC analysis was $1 \mu \mathrm{L}$. Each analysis run took around $25.7 \mathrm{~min}$. Data handling was carried out with Chemstation software. Calibration curves were constructed using a standard SCFA solution by comparing the peak areas $\left(\mathrm{mAU}^{*} \mathrm{~s}\right)$ for samples at similar retention times. All samples were analyzed in duplicate, whereas SCFA standards of acetic acid, propionic acid and butyric acid were used to determine the concentration of SCFAs in the samples.

\section{Statistical analysis}

All experiments were carried out at least in duplicate and the results are expressed as mean and standard deviation. To determine if there were differences in the growth of microorganisms from fifteen randomized views an analysis of variance (ANOVA) was performed using SPSS (Statistical Software, Inc., Chicago, IL), version 21.0, with $p<0.05$ required for statistical significance and post hoc analysis with Duncan's test.

\section{Results and discussion}

\subsection{Gut microbiota population}

All the samples tested show selective fermentation with greater increases in bifidobacteria than in the other strains of non-beneficial bacteria. There was selective modulation of the bacterial growth on each substrate. The bacterial population of bifidobacteria is shown in Figure 1. Significant increase in bifidobacterial population was observed on POG $(10.06 \pm 0.06 \log$ cell $/ \mathrm{mL})$ and KOG $(9.99 \pm 0.09 \mathrm{log} / \mathrm{mL})$ after $12 \mathrm{~h}$ fermentation, and on PGM $(9.12 \pm 0.05 \log$ cell $/ \mathrm{mL})$ after $24 \mathrm{~h}$. However, the number of bifidobacteria stayed elevated until the end of incubation (48 h), particularly on POG and KOG. Thus, these might have bifidogenicity selectively stimulating the growth of bifidobacteria. According to Yang et al. (2017) KOG, an enzymatic hydrolysis product, has prebiotic effect supporting the growth of desirable bacteria, such as bifidobacteria. In this current study POG and KOG addition led to bifidobacteria becoming the numerically predominant genus in batch culture fermentation. However, bifidobacteria hydrolyze actively degrading the polysaccharides in the later parts of fermentation (Wichienchot et al., 2006). So, in this study PGM successfully stimulated the growth of bifidobacteria, increasingly after $24 \mathrm{~h}$. Actually, the substances with low molecular weight oligosaccharides can be more easily fermented by specific enteric microbiota, especially bifidobacteria and lactobacilli, which demonstrated the greatest bifidogenic effect (Wichienchot et al., 2006). Konjac oligo-glucomannan has been reported on bifidogenic effect and amelioration of gut dysbiosis and gastrointestinal motility in rats (Hayeeawaema et al., 2020).

The lactobacilli population (Figure 1b) increased significantly $(p<0.05)$ after $12 \mathrm{~h}(9.81 \pm 0.05 \log$ cell $/ \mathrm{mL})$ for POG and $(9.71$ $\pm 0.02 \log$ cell $/ \mathrm{mL}$ ) for KOG. The PGM fermentation showed a similar high population of lactobacilli $(9.68 \pm 0.03 \mathrm{log}$ cell $/ \mathrm{mL})$ still after $48 \mathrm{~h}$. These results indicate that lactobacilli could be more stimulated by the short POG or KOG oligosaccharides. In addition, PGM could be metabolized by lactobacilli over an extended period. According to Harmayani et al. (2014) PGM has little impact on the growth of bifidobacteria and lactobacilli. This may due to PGM had high molecular weight and a strong hydrogen bonding formed during thermal processing to produce PGM flour. The substrate with high molecular weight and complex molecule may retard on fermentability by gut microbiota. However, actually glucomannan can be consumed by beneficial colonic bacteria to produce oligosaccharides or monosaccharides (Pokusaeva et al., 2011).

The bacteroides population (Figure 1c) decreased significantly $(p<0.05)$ after $12 \mathrm{~h}(9.17 \pm 0.04 \mathrm{log}$ cell $/ \mathrm{mL}, \mathrm{KOG}$ and $9.02 \pm$ $0.04 \log$ cell $/ \mathrm{mL}, \mathrm{POG}$ ) and kept decreasing gradually with fecal fermentation. POG substrate reduced the growth of bacteroides. On the other hand, a significant $(p<0.05)$ decrease of bacteroides population on PGM was observed at $24 \mathrm{~h}$ of fermentation $(9.26 \pm 0.03 \log$ cell $/ \mathrm{mL})$. Harmayani et al. (2014) reported that the prebiotic activity of PGM in vivo suppressed the growth of E. coli. These trends of bacteroides population were similar with clostridia population, whilst KOG had more potential to suppress clostridia than POG. The growth of clostridia is summarized in Figure 1d. A previous study on hydrolyzed glucomannan showed 
a)

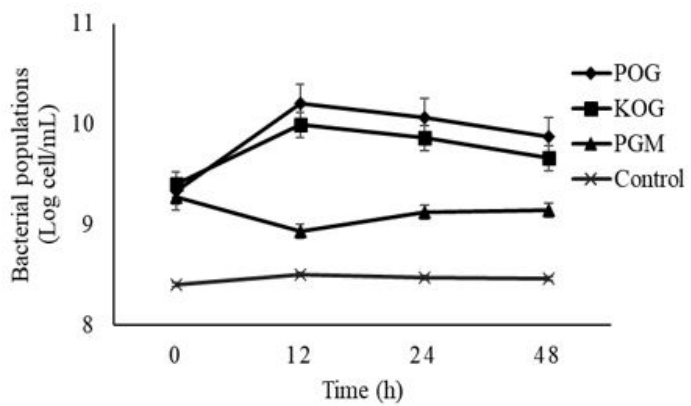

c)

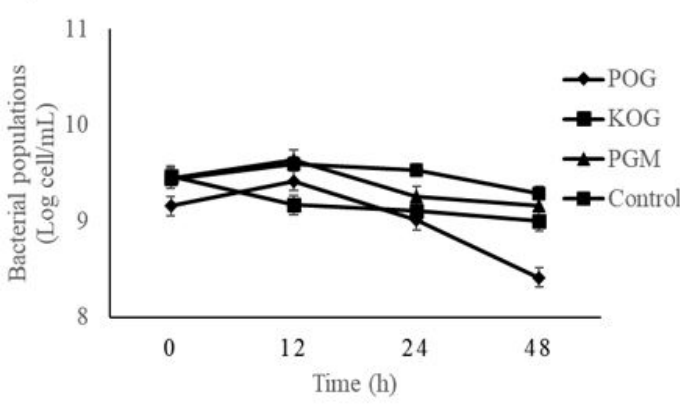

e)

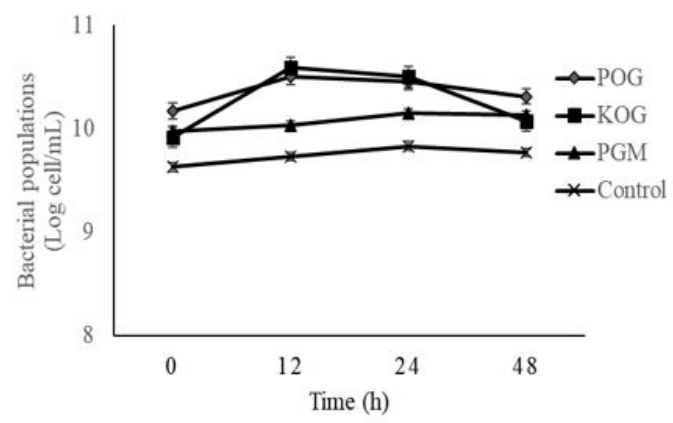

b)

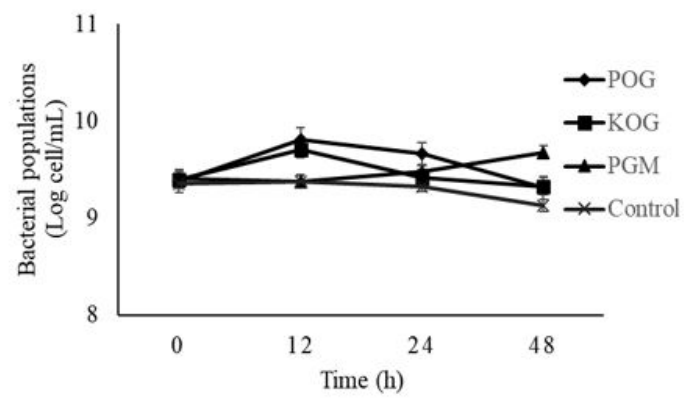

d)

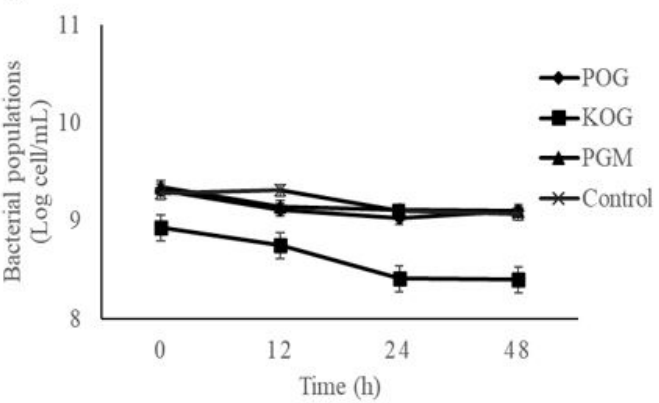

Figure 1. Gut microbiota populations of (a) bifidobacterial; (b) lactobacilli; (c) bacteroides; (d) clostridia; and (e) eubacteria in batch culture fermentation of porang oligo-glucomannan (POG).

more inhibition of clostridia population than with prebiotic inulin (Connolly et al., 2010).

In Figure 1e showing the effect of each substrate on eubacteria, the highest population was in POG fermentation $(10.50 \pm 0.02 \log$ cell $/ \mathrm{mL})$ with significantly difference $(p<0.05)$ to other substrates. The increase in the population of beneficial bacteria is larger than the decrease in pathogen bacterial populations, so the total bacterial count increases. Connolly et al. (2010) reported that the total bacterial population of glucomannan hydrolysate and prebiotic inulin fermentation did not differ significantly $(p>0.05)$.

\subsection{Prebiotic activity}

Prebiotic index (PI) indicates the growth of microorganism with stimulation by the tested substrates when compared to
Table 1. Prebiotic index (PI) of porang oligo-glucomannan (POG).

\begin{tabular}{cc}
\hline Sample & Prebiotic index $(\mathrm{PI})$ \\
\hline PGM & 4.25 \\
POG & 10.29 \\
KOG & 8.53 \\
Control & 1.31 \\
\hline
\end{tabular}

control substrate (Palframan et al., 2002). It represents both growth stimulation of positive bacteria (bifidobacteria and lactobacilli) and of negative bacteria (bacteroides and clostridia). PI obtained for the different substrates is shown in Table 1, and in rank order POG is followed by KOG and PGM with PI values of $10.29,8.53$, and 4.25 , respectively. Moreover, POG showed to be a more effective prebiotic than the other substrates, stimulating the growth of beneficial bacteria: particularly on bifidobacteria 
while suppressing the growth of pathogenic bacteria. For a long time, galactooligosaccharides (GOS) have been the best type of prebiotic with the high prebiotic index of 6.68 , known as commercial prebiotic, followed by FOS and inulin that also have good prebiotic indexes (Wichienchot et al., 2017). In this current study, the POG would have been competitive with products on the market.

The previous study of Ariestanti et al. (2019) on prebiotic activity of PGM in fecal batch culture showed that it supports a number of beneficial bacteria, especially bifidobacteria. However, they reported that KOG with a lower molecular weight showed more prebiotic potency than either commercial inulin or its native glucomannan. The results in this study showed the ability of hydrolyzed products (POG and KOG) to selectively promote the growth of bifidobacteria.

\subsection{Short chain fatty acid production}

Short chain fatty acids are the major product of bacterial fermentation from carbohydrates in colon. Table 2 shows the concentrations of SCFAs in POG, KOG, PGM, and control. In this study, acetic acid was the most SCFA produced in all fermentations. According to Ariestanti et al. (2019) and RíosCovián et al. (2016) were found that acetic acid is the main SCFA generated during fermentation. However, acetic acid concentration in those studies are lower than this study.

POG showed the most acetic acid production among all of the substrates tested, and together with KOG maintained a high acetate concentration to the end of the fermentation at $48 \mathrm{~h}$. PGM had a significantly higher level $(p<0.05)$ at $48 \mathrm{~h}$, while the level was increased but no significant $(p>0.05)$ different during 0-24 h of fecal fermentation.

Regarding propionic production, POG shows an initial increase in fermentation and then constant trend. The increase was significant $(p<0.05)$ at $12 \mathrm{~h}$ for POG and at $24 \mathrm{~h}$ for KOG (9.20 mM, 8.72 mM, respectively). According to Wichienchot et al. (2017) propionic acid forms in the beginning of incubation and decreases later. Meanwhile, PGM showed significant increase $(p<0.05)$ at $48 \mathrm{~h}$ of fecal fermentation $(7.56 \mathrm{mM})$. Propionic acid is only produced by specific combinations of substrates and bacterial strains (Morrison \& Preston, 2016).

On the other hand, butyric acid was produced with similar trend as propionic, with POG and KOG significantly $(p<0.05)$ produced during initial fecal fermentation (12 h). POG show a significant increase of butyric acid from 3.58 to $6.68 \mathrm{mM}$ within $12 \mathrm{~h}$ and kept increase until $48 \mathrm{~h}$. Meanwhile KOG show a significant increase of butyric acid from 6.44 to $7.04 \mathrm{mM}$ at $24 \mathrm{~h}$ and kept increase until $48 \mathrm{~h}$. PGM took longer fermentation time $(48 \mathrm{~h})$ to see the significant increase of butyric acid.

In addition, POG and KOG as hydrolyzed glucomannans might have potential butyrogenicity with a role for human health. According to Al-Sheraji et al. (2013) butyric acid is the main source of energy for colonocytes. These form a barrier maintaining the epithelial cells by stimulating mucin secretion, antimicrobial peptides, tight-junction protein, boosting immune system and reducing oxidative stress in the colon (Al-Sheraji et al., 2013; Rivière et al., 2016). According to Tester \& Al-Ghazzewi (2017) butyrate can be considered most beneficial for colonic health. In addition, the specific role of butyrate in gut health

Table 2. Short-chain fatty acids (SCFA) production in fecal batch culture fermentation of porang oligo-glucomannan (POG).

\begin{tabular}{|c|c|c|c|c|}
\hline \multirow{2}{*}{ Sample } & \multicolumn{4}{|c|}{ SCFA concentration $(\mathrm{mM})$} \\
\hline & Acetate & Propionate & Butyrate & Total SCFA \\
\hline \multicolumn{5}{|l|}{ Control } \\
\hline $0 \mathrm{~h}$ & $5.65 \pm 0.95^{c}$ & $2.08 \pm 0.20^{c}$ & $1.61 \pm 0.13^{b}$ & $9.34 \pm 1.27^{\mathrm{b}}$ \\
\hline $12 \mathrm{~h}$ & $7.06 \pm 0.57^{\mathrm{bc}}$ & $2.45 \pm 0.07^{b c}$ & $1.73 \pm 0.04^{\mathrm{ab}}$ & $11.24 \pm 0.68^{\mathrm{ab}}$ \\
\hline $24 \mathrm{~h}$ & $7.75 \pm 0.55^{\mathrm{ab}}$ & $2.62 \pm 0.17^{\mathrm{ab}}$ & $1.76 \pm 0.08^{\mathrm{ab}}$ & $12.13 \pm 0.81^{\mathrm{ab}}$ \\
\hline $48 \mathrm{~h}$ & $8.85 \pm 0.13^{\mathrm{a}}$ & $2.88 \pm 0.08^{\mathrm{a}}$ & $1.87 \pm 0.04^{\mathrm{a}}$ & $13.60 \pm 0.25^{\mathrm{a}}$ \\
\hline \multicolumn{5}{|l|}{ POG } \\
\hline $0 \mathrm{~h}$ & $32.64 \pm 2.88^{\mathrm{a}}$ & $5.82 \pm 0.42^{\mathrm{b}}$ & $3.58 \pm 0.14^{\mathrm{b}}$ & $42.04 \pm 3.45^{\mathrm{a}}$ \\
\hline $12 \mathrm{~h}$ & $31.48 \pm 2.77^{\mathrm{a}}$ & $9.20 \pm 0.11^{\mathrm{a}}$ & $6.68 \pm 0.06^{\mathrm{a}}$ & $47.36 \pm 2.94^{\mathrm{a}}$ \\
\hline $24 \mathrm{~h}$ & $30.16 \pm 0.11^{\mathrm{a}}$ & $9.16 \pm 0.06^{\mathrm{a}}$ & $6.92 \pm 0.06^{\mathrm{a}}$ & $46.24 \pm 0.11^{\mathrm{a}}$ \\
\hline $48 \mathrm{~h}$ & $29.72 \pm 7.64^{\mathrm{a}}$ & $9.44 \pm 1.13^{\mathrm{a}}$ & $7.28 \pm 0.68^{\mathrm{a}}$ & $46.44 \pm 09.45^{\mathrm{a}}$ \\
\hline \multicolumn{5}{|l|}{ KOG } \\
\hline $0 \mathrm{~h}$ & $25.20 \pm 0.91^{\mathrm{b}}$ & $8.08 \pm 0.11^{\mathrm{c}}$ & $6.44 \pm 0.06^{c}$ & $39.72 \pm 0.74^{\mathrm{b}}$ \\
\hline $12 \mathrm{~h}$ & $24.28 \pm 0.28^{b}$ & $8.12 \pm 0.06^{c}$ & $6.64 \pm 0.11^{c}$ & $39.04 \pm 0.45^{b}$ \\
\hline $24 \mathrm{~h}$ & $27.00 \pm 2.09^{b}$ & $8.72 \pm 0.34^{b}$ & $7.04 \pm 0.23^{b}$ & $42.76 \pm 2.66^{\mathrm{b}}$ \\
\hline $48 \mathrm{~h}$ & $31.52 \pm 0.23^{\mathrm{a}}$ & $9.56 \pm 0.06^{\mathrm{a}}$ & $7.72 \pm 0.06^{\mathrm{a}}$ & $48.80 \pm 0.34^{\mathrm{a}}$ \\
\hline \multicolumn{5}{|l|}{ PGM } \\
\hline $0 \mathrm{~h}$ & $8.80 \pm 0.17^{b}$ & $3.92 \pm 0.40^{\mathrm{b}}$ & $3.04 \pm 0.17^{b}$ & $15.76 \pm 0.40^{\mathrm{b}}$ \\
\hline $12 \mathrm{~h}$ & $13.00 \pm 1.81^{\mathrm{b}}$ & $4.02 \pm 0.37^{b}$ & $2.98 \pm 0.08^{b}$ & $20.00 \pm 2.26^{\mathrm{b}}$ \\
\hline $24 \mathrm{~h}$ & $13.74 \pm 1.16^{\mathrm{b}}$ & $4.00 \pm 0.23^{\mathrm{b}}$ & $2.98 \pm 0.08^{\mathrm{b}}$ & $20.72 \pm 1.47^{b}$ \\
\hline $48 \mathrm{~h}$ & $27.08 \pm 5.26^{\mathrm{a}}$ & $7.56 \pm 1.47^{\mathrm{a}}$ & $5.30 \pm 0.93^{\mathrm{a}}$ & $39.94 \pm 7.67^{\mathrm{a}}$ \\
\hline
\end{tabular}

Values are given as mean \pm SD of duplicate fermentation; Different letters indicate significant differences $(p<0.05)$ within a column) in the same sample. 
by preventing attack of pathogen bacteria to epithelial cell has been reported (Al-Ghazzewi \& Tester, 2014).

\section{Conclusions}

Porang oligo-glucomannan (POG) showed butyrogenicity through elevating SCFA production, especially the butyric acid concentration, more so than the other tested substrates. Despite its bifidogenic effect mainly favoring bifidobacteria it had a tendency to suppress the pathogenic bacteria. The prebiotic index of POG was favorable at 10.29 . The butyrogenicity and bifidogenicity of POG indicate it as a candidate functional ingredient to improve human health. POG stimulated the growth of lactobacilli and bifidobacteria. The unique properties of POG make it potentially valuable in many foods as a prebiotic, when it is useful to promote the growth of lactobacilli and bifidobacteria.

\section{Acknowledgements}

This work was supported by research grants from the Graduate School, Prince of Songkla University, Hat Yai, Songkhla, Thailand under the master dual degree program both of Prince of Songkla University, Thailand and Gadjah Mada University, Indonesia.

\section{References}

Al-Ghazzewi, F. H., \& Tester, R. F. (2014). Inhibition of the adhesion of Escherichia coli to human epithelial cells by carbohydrates. Bioactive Carbohydrates and Dietary Fibre, 4(1), 1-5. http://dx.doi. org/10.1016/j.bcdf.2014.05.001.

Al-Sheraji, S. H., Ismail, A., Manap, M. Y., Mustafa, S., Yusof, R. M., \& Hassan, F. A. (2013). Prebiotics as functional foods. Journal of Functional Foods, 5(4), 1542-1553. http://dx.doi.org/10.1016/j. jff.2013.08.009.

Anggela, Setyaningsih, W., Wichienchot, S., \& Harmayani, E. (2020). Oligo-glucomannan production from porang (Amorphophallus oncophyllus) by enzymatic hydrolysis using $\beta$-mannanase. Indonesian Food and Nutrition Progress, 17(1), 23-27. http://dx.doi.org/10.22146/ ifnp.57217.

Ariestanti, C. A., Seechamnanturakit, V., Harmayani, E., \& Wichienchot, S. (2019). Optimization on production of konjac oligo-glucomannan and their effect on the gut microbiota. Journal of Food Science and Nutrition, 7(2), 788-796. PMid:30847158.

Behera, S. S., \& Ray, R. C. (2016). Konjac glucomannan, a promising polysaccharide of Amorphophallus konjac K. Koch in health care. International Journal of Biological Macromolecules, 92, 942-956. http://dx.doi.org/10.1016/j.ijbiomac.2016.07.098. PMid:27481345.

Budi, S. D., Bambang, S., \& Munawar. (2018). Forest community empowerment through the increasing role of productive cropbased SMIS around forest: a study on porang plants in East Java, Indonesia. Russian Journal of Agricultural and Socio-Economic Sciences, 12(84), 260-274.

Chen, H. L., Cheng, H. C., Wu, W. T., Liu, Y. J., \& Liu, S. Y. (2008). Supplementation of konjac glucomannan into a low-fiber Chinese diet promoted bowel movement and improved colonic ecology in constipated adults: a placebo-controlled trial. Journal of the American College of Nutrition, 27(1), 102-108. http://dx.doi.org/10.1080/073 15724.2008.10719681. PMid:18460488.

Connolly, M. L., Lovegrove, J. A., \& Tuohy, K. M. (2010). Konjac glucomannan hydrolysate beneficially modulates bacterial composition and activity within the faecal microbiota. Journal of Functional Foods, 2(3), 219-224. http://dx.doi.org/10.1016/j.jff.2010.05.001.

Donohoe, D. R., Garge, N., Zhang, X., Sun, W., O’Connell, T. M., Bunger, M. K., \& Bultman, S. J. (2011). The microbiome and butyrate regulate energy metabolism and autophagy in the mammalian colon. Cell Metabolism, 13(5), 517-526. http://dx.doi.org/10.1016/j. cmet.2011.02.018. PMid:21531334.

Flint, H. J., Scott, K. P., Duncan, S. H., Louis, P., \& Forano, E. (2012). Microbial degradation of complex carbohydrates in the gut. Gut Microbes, 3(4), 289-306. http://dx.doi.org/10.4161/gmic.19897. PMid:22572875.

Gibson, G. R., Hutkins, R., Sanders, M. E., Prescott, S. L., Reimer, R. A., Salminen, S. J., Scott, K., Stanton, C., Swanson, K. S., Cani, P. D., Verbeke, K., \& Reid, G. (2017). The International Scientific Association for Probiotics and Prebiotics (ISAPP) consensus statement on the definition and scope of prebiotics. Nature Reviews. Gastroenterology \& Hepatology, 14(8), 491-502. http://dx.doi. org/10.1038/nrgastro.2017.75. PMid:28611480.

Harmayani, E., Aprilia, V., \& Marsono, Y. (2014). Characterization of glucomannan from Amorphophallus oncophyllus and its prebiotic activity in vivo. Carbohydrate Polymers, 112, 475-479. http://dx.doi. org/10.1016/j.carbpol.2014.06.019. PMid:25129770.

Hayeeawaema, F., Wichienchot, S., \& Khuituan, S. (2020). Amelioration of gut dysbiosis and gastrointestinal motility by konjac oligo-glucomannan on loperamide-induced constipation in mice. Nutrition, 73, 110715. http://dx.doi.org/10.1016/j.nut.2019.110715. PMid:32135415.

Hugenholtz, P., Tyson, G. W., \& Blackall, L. L. (2002). Design and evaluation of $16 \mathrm{~S}$ rRNA-targeted oligonucleotide probes for fluorescence in situ hybridization. Methods in Molecular Biology, 179, 29-42. PMid:11692872.

Morrison, D. J., \& Preston, T. (2016). Formation of short chain fatty acids by the gut microbiota and their impact on human metabolism. Gut Microbes, 7(3), 189-200. http://dx.doi.org/10.1080/19490976.2 015.1134082. PMid:26963409.

Palframan, R. J., Gibson, G. R., \& Rastall, R. A. (2002). Effect of pH and dose on the growth of gut bacteria on prebiotic carbohydrate in vitro. Anaerobe, 8(5), 287-292. http://dx.doi.org/10.1006/anae.2002.0434. PMid:16887671.

Plongbunjong, V., Graidist, P., Knudsen, K. E. B., \& Wichienchot, S. (2017). Isomaltooligosaccharide synthesised from rice starch and its prebiotic properties in vitro. International Journal of Food Science \& Technology, 52(12), 2589-2595. http://dx.doi.org/10.1111/ijfs.13545.

Pokusaeva, K., Fitzgerald, G. F., \& Van Sinderen, D. (2011). Carbohydrate metabolism in bifidobacteria. Genes \& Nutrition, 6(3), 285-306. http://dx.doi.org/10.1007/s12263-010-0206-6. PMid:21484167.

Ríos-Covián, D., Ruas-Madiedo, P., Margolles, A., Gueimonde, M., De los Reyes-Gavilán, C. G., \& Salazar, N. (2016). Intestinal short chain fatty acids and their link with diet and human health. Frontiers in Microbiology, 7, 185. http://dx.doi.org/10.3389/fmicb.2016.00185. PMid:26925050.

Rivière, A., Selak, M., Lantin, D., Leroy, F., \& De Vuyst, L. (2016). Bifidobacteria and butyrate-producing colon bacteria: Importance and strategies for their stimulation in the human gut. Frontiers in Microbiology, 7, 979. http://dx.doi.org/10.3389/fmicb.2016.00979. PMid:27446020.

Scott, K. P., Duncan, S. H., \& Flint, H. J. (2008). Dietary fibre and the gut microbiota. Journal Compilation Nutrition Bulletin, 33(3), 201211. http://dx.doi.org/10.1111/j.1467-3010.2008.00706.x.

Scott, K. P., Gratz, S. W., Sheridan, P. O., Flint, H. J., \& Duncan, S. H. (2013). The influence of diet on the gut microbiota. Pharmacological 
Research,69(1), 52-60. http://dx.doi.org/10.1016/j.phrs.2012.10.020. PMid:23147033.

Sossai, P. (2012). Butyric acid: what is the future for this old substances. The European Journal of Medical Sciences, 142, w13596. http://dx.doi. org/10.4414/smw.2012.13596. PMid:22674349.

Tedelind, S., Westberg, F., Kjerrulf, M., \& Vidal, A. (2007). Antiinflammatory properties of the short-chain fatty acids acetate and propionate: A study with relevance to inflammatory bowel disease. World Journal of Gastroenterology, 13(20), 2826-2832. http://dx.doi. org/10.3748/wjg.v13.i20.2826. PMid:17569118.

Tester, R., \& Al-Ghazzewi, F. (2017). Glucomannans and nutrition. Food Hydrocolloids, 68, 246-254. http://dx.doi.org/10.1016/j. foodhyd.2016.05.017.
Wichienchot, S., Prakobpran, P., Ngampanya, B., \& Jaturapiree, P. (2017). Production, purification and fecal fermentation of fructooligosaccharide by FTase from Jerusalem artichoke. International Food Research Journal, 24(1), 134-141.

Wichienchot, S., Prasertsan, P., Hongpattarakere, T., Gibson, G. R., \& Rastall, R. A. (2006). In vitro fermentation of mixed linkage glucooligosaccharides produced by Gluconobacter oxydans NCIMB 4943 by the human colonic microflora. Current Issues in Intestinal Microbiology, 7(1), 7-12. PMid:16570694.

Yang, J., Vittori, N., Wang, W., Shi, Y. C., Hoeflinger, J. L., Miller, M. J., \& Pan, Y. (2017). Molecular weight distribution and fermentation of mechanically pre-treated konjac enzymatic hydrolysates. Carbohydrate Polymers, 159, 58-65. http://dx.doi.org/10.1016/j. carbpol.2016.12.014. PMid:28038754. 